\title{
Socio-economic Factors Influencing Nile Tilapia Aquaculture in Kenya
}

\author{
Martha K. Muteti ${ }^{1},{ }^{*}$ Michael N.I. Lokuruka ${ }^{2}$ and Andrew W. Yasindi ${ }^{3}$ \\ 1-Mwea AquaFish Farm P.O. Box 101040-00100, Nairobi \\ E-mail: muteti_martha@yahoo.com \\ 2-Department of Food Science and Nutrition, Karatina University, Box 1957-10101, Karatina, Kenya. \\ E-mail:mlokuruka@gmail.com; mlokuruka@,karu.ac.ke \\ 3-Department of Biological Sciences, Egerton University, P.O. Box 536-20115, Nakuru, Kenya; E- \\ mail: ayasindi@yahoo.com \\ * Corresponding author: Michael N.I. Lokuruka. Telephone: +254-726155273 \\ E-mail; mlokuruka@gmail.com \\ https://doi.org/10.37512/200
}

\begin{abstract}
This study aimed to unravel the factors that may be contributing to the declining aquaculture output in Kenya. The project obtained data using a semi-structured questionnaire, expert interviews and observations in Bomet, Kericho and Nakuru counties of Kenya. Eighteen farms, rearing Nile tilapia by semi-intensive method, with fifteen using on-farm formulated feeds, were purposively selected. Three of them, one per County, and all using commercial feed, served as the control. The study investigated on-farm feed formulation practices, ingredient and feed storage methods, production costs and training service provision. Nakuru County recorded the highest cost per gram of protein, while Bomet County recorded the lowest unit cost $(p<0.05)$. Fifty five percent of farmers used the Pearson Square Method for fish feed formulation, with most of them being from Nakuru County and the least coming from Kericho County. Sixty percent of participating farmers were appropriately trained. The study recommends that the State Department of Fisheries and Blue Economy and Counties make aquaculture a major operational and results area. Additionally, credit to farmers and subsidy of cost of inputs should be provided alongside appropriate extension services.
\end{abstract}

KEY WORDS: Socio-economic factors, Aquaculture, Nile Tilapia, Kenya

\section{INTRODUCTION}

The increasing world population has led to a global focus on food security and sustainable strategies of food production. Aquaculture tops the list of the sectors most governments are currently giving attention to for food security and poverty reduction. Aquaculture has been recognised as one of the fastest -growing food-producing sectors in the world (FAO, 2015). This is attributed to the increase in fish consumption and production. In 2013, fish represented 16 percent of all animal protein consumed by humans globally (FAO, 2015).

Kenya's capture fisheries and aquaculture sectors contribute approximately 0.54 percent to the country's Gross Domestic Product (FAO, 2013). The total fishery and aquaculture production in 2016 amounted to 147,916 and 14,952 metric tons, respectively (GoK, 2016). The contribution from aquaculture, however, declined in the year under review, from 18,656 metric tons in 2015 (GoK, 2015). As the development of aquaculture remains a priority to the Kenya Government, various initiatives have been undertaken to encourage farming and consumption of fish and to attract investments in the sector. These ideas gained momentum in 2009-2010 through a government initiative dubbed "Economic Stimulus Program", whose aim was economic 
development and poverty alleviation (GoK, 2013).

Despite the success stories in the sector, aquaculture in Kenya still faces challenges which have resulted in stagnation of the industry, and a sudden decline which was experienced from 2014 upwards (Figure 1)

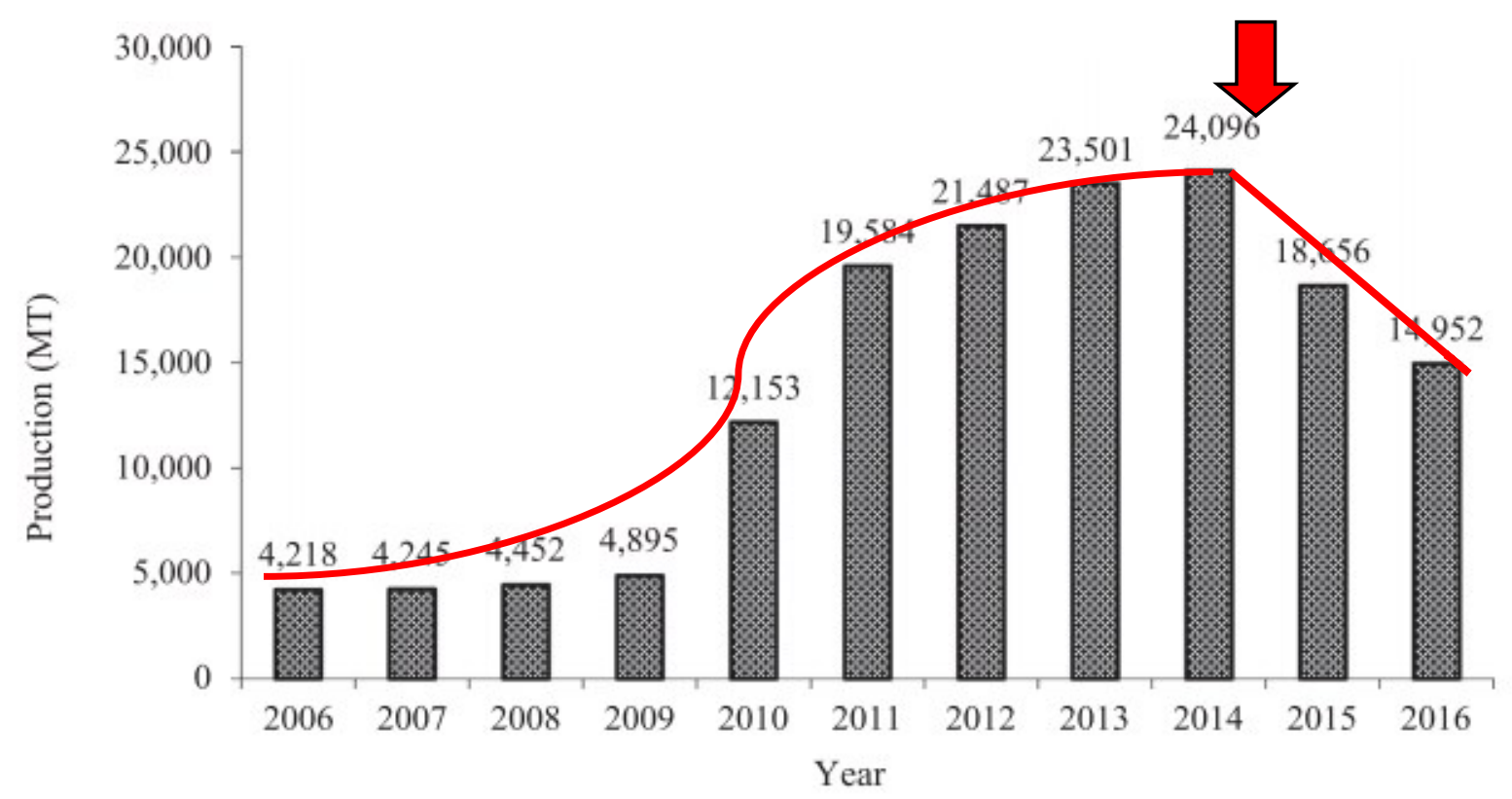

Figure 1: Aquaculture production in Kenya in metric tons (2006-2016).

Source: (Kenya National Bureau of Statistics-KNBS, 2017).

Some of the challenges are lack of readily available and affordable quality fish seed and feed, poor adoption of recommended fish husbandry techniques by some farmers and inadequate market information. These were some of the constraints highlighted in the Annual Fishery Statistical Report by the Ministry of Agriculture, Livestock and Fisheries (2015). The problem of inadequate quality and affordable fish feeds tops the list of these challenges. Furthermore, it has been widely reported by researchers and experienced by most fish farmers in the country. This problem stands out for the reason that fish feed accounts for more than 40 percent of total fish production cost (Abowei et al., 2012). With the small number of certified commercial fish feed producers in the country and the increased fish feed demand due to the increasing number of farmers in the sector, the result is inadequate feeds in the market. Producers are also scattered all over the country and for this reason, farmers travel long distances to obtain the feeds which results in high travel costs and eventually high costs of production (Liti et al., 2005).
The exorbitant prices of commercial fish feeds, has slowed down the growth of aquaculture in many parts of Kenya. To counter this problem, farmers have opted to use locally available ingredients to formulate feeds on-farm at lower costs. Limited information is currently available on the quality of feeds formulated by small scale farmers in most parts of the country, especially for pond and tank culture. There is therefore need for the compositional analysis of onfarm formulated feeds, how they are formulated and the technical knowhow of farmers on various management practises, to ensure that they meet the Kenyan fish feed standards for Nile Tilapia farming. This study therefore aimed at assessing the aforementioned aspects of aquaculture production of Nile Tilapia by the semi-intensive method. However, the compositional analysis of on-fam formulated feeds for quality is described elsewhere and will therefore not be part of the current discussion.

Estimates of costs incurred in the formulation of the on-farm made feeds, was also assessed, as well as the feed management practises being used by the small scale fish farmers. 


\section{MATERIALS AND METHODS \\ Study area}

The study was carried out in 2016-2017 on selected fish farms in Nakuru, Kericho and Bomet Counties of the Rift Valley Region of Kenya. The data collection sites are shown in Figure 2. This region is of interest because in recent years, fish farming has become a point of attention (Ngugi, 2009). This has been attributed to the desire by farmers to increase farm production per unit area, as land area for food production continues to decline (State Department of Fisheries and Blue Economy, 2016)

The main crops cultivated in these counties include; maize, wheat, tea, vegetables and fruits (Lukuyu et al., 2011) These crops are a potential source of local fish feed ingredients, thus making the region potentially suitable for sustainable and cost-effective aquaculture. Moreover, the temperature range of $10-28^{\circ} \mathrm{C}$ in this region is favourable for Nile Tilapia culture (Bowman et al., 2007). Fish production in the Rift Valley Region is largely semi-intensive, with more than 3,000,000 $\mathrm{m}^{2}$ of culture area established (Ngugi, 2009).

\section{Criteria Applied at Farm Selection}

Farms were selected from the three counties, based on the selection criteria given below:

i. Small scale farms using semi-intensive method of farming Nile Tilapia with at least one pond to a maximum of 4 ponds.

ii. Farms that used on-farm formulated feeds, with single or mixed ingredients.

A pilot survey was conducted before the start of the study to determine the farms to work with based on the above selection criteria. Thirty five farms were selected randomly, with fourty percent of them being sampled, giving a total of fourteen farms. One farm using commercial fish feed was picked from each county for comparison. This made a sample total of eighteen farms rearing Nile Tilapia by semi-intensive culture. Data on training provision for farmers and the applicable feed management practises was obtained through observations and survey using a semi-structured questionnaire.

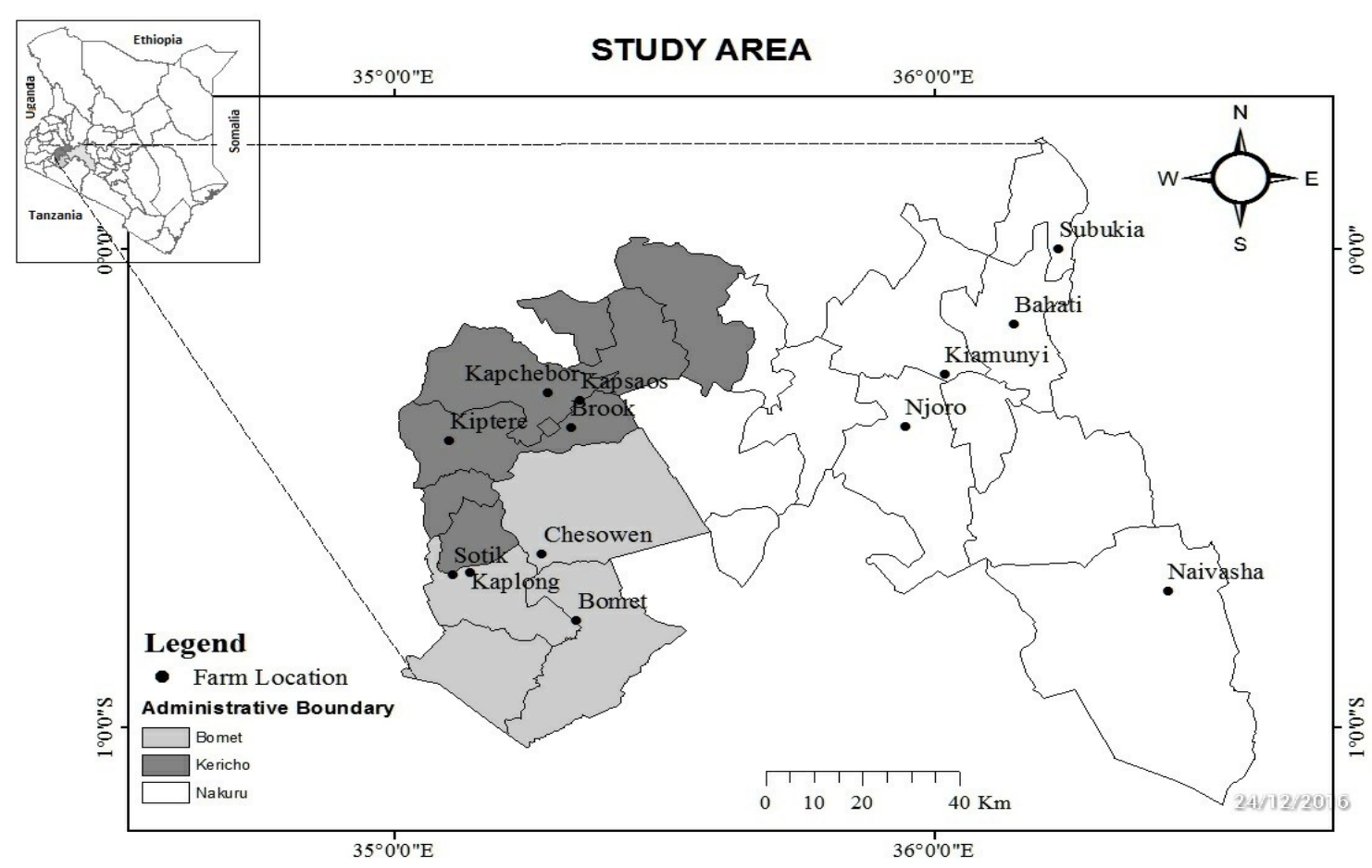

Figure 2: A map of Kenya showing the counties in the Rift Valley Region and fish farms where the study was undertaken. 


\section{Feed Cost Analysis}

The unit market prices of individual ingredients used were obtained, then the best-buy technique was used to compare the ingredients with one another on the basis of cost per unit of protein or lipids, depending on what major nutrient the ingredients/feeds are supposed to provide.

Cost per unit of protein $=$ cost per gram of feed/amount of protein per gram of feed

N.B: Best-buy formula (Bhosale et al., 2010)

\section{DATA ANALYSIS}

One-way ANOVA test was performed to compare differences in means of nutrient content of commercial and on-farm formulated feeds and the Official Standards; the mean costs of on-farm formulations and commercial feeds between and among counties were also compared.

\section{RESULTS AND DISCUSSION}

\section{Method of Feed Formulation}

Guided by the main objective of this study, it was important to assess the results of the methods used by the fish farmers to formulate fish feeds on-farm. This was done through the use of structured interviews and observations. The results of this aspect of fish production are shown in Figures 3a and $3 \mathrm{~b}$. More than half of the farmers interviewed
(55\%) used the Pearson's Square Method to formulate fish feeds on-farm. The rest of the farmers used trial and error methods, in which the various ingredients were mixed without measuring their proportions unlike in the Pearson's Square Method. It was evident that Pearson's Square Method was used across the three counties (Figure 3a) but most widely in Nakuru County, where $35 \%$ of the farms used the method (Figure 3b).
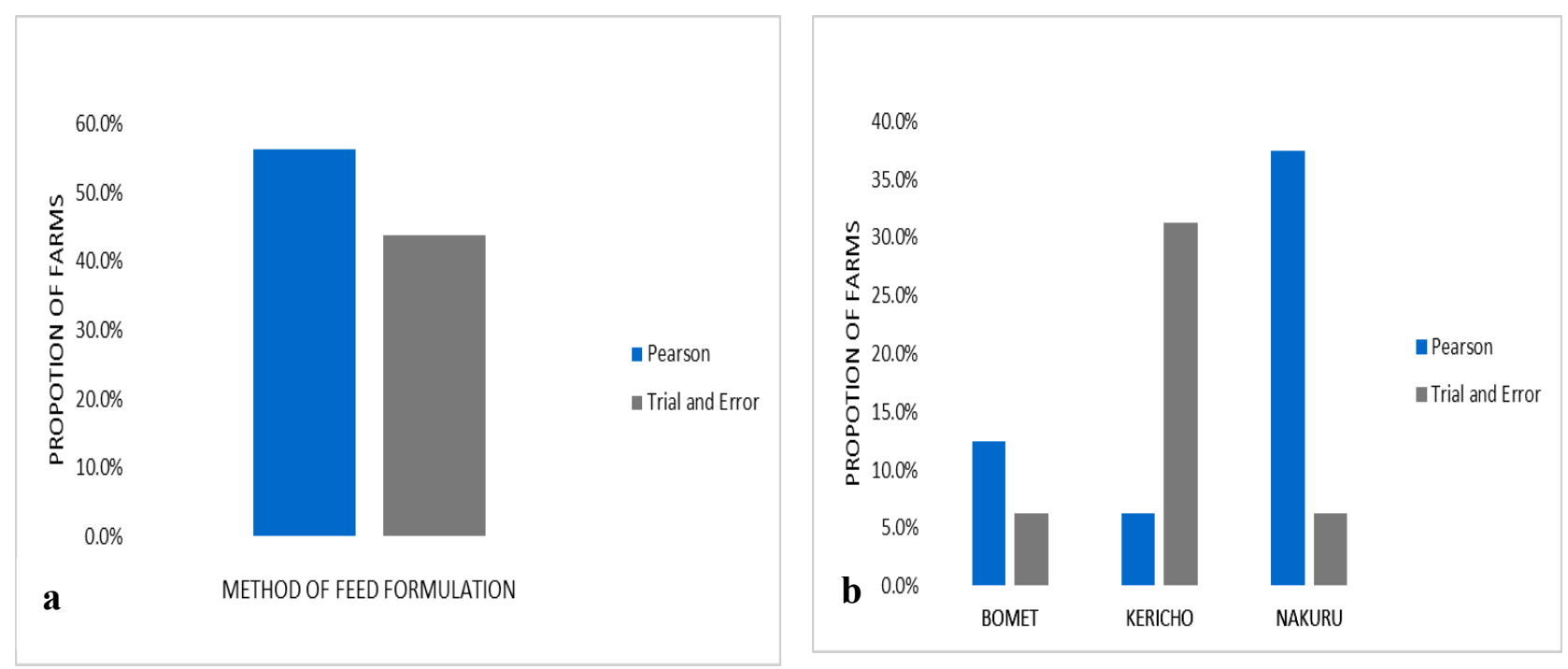

Figure 3a and 3b: Methods of feed formulation in the three counties

\section{Fish Feed Costs}

The cost per gram of on-farm formulated feed was determined through interviews and market price surveys, which was then divided by the protein content in a gram of the feed (Bhosale et al., 2010). Protein was used here because of its importance in the growth of fish and because it is usually the most expensive ingredient in fish feeds. Nakuru farm 1 and 3 recorded the highest value in terms of the cost per gram of protein. On the other hand, Kericho farm 3, 4 and Nakuru farm 5 and 6 recorded the lowest values (Figure 5). The high cost 
of feeds was because the manufacturers and a few farms imported the ingredients to make feeds. These included shrimps, fish meal, cotton seed cake and sunflower oil. The farms with lower feed costs, mostly utilized local ingredients. Examples of these ingredients included: Leucena Trichandra leaves, avocado fruit, kales, poultry and kitchen wastes, which were obtained from the farm and in the homestead. In terms of counties, Nakuru County recorded the highest cost per gram of feed. Most farms in Kericho and Bomet recorded the lowest values $(p<0.05)$. These results are given in Figures 4 and 5 .

In this study, it was found that fish feeds containing locally available ingredients were cheaper than those containing imported ingredients. This agrees with Musiba et al. (2014) who established that locally made fish feeds can be used cost-effectively to produce fish feeds. The difference is mainly due to the high transportation costs incurred in sourcing the ingredients from distant places. It can also be attributed to the fact that ingredients such as fish meal and shrimps have continually reduced in supply due to dwindling stocks in inland fisheries and the high competition faced as these ingredients may also be used in poultry and other animal feeds manufacture. Seasonality of ingredients such as Rastrineobola argentea or "omena" also contributes to the high prices, especially during low seasons. Kwikiriza et al. (2016) showed that some farmers spent a lot of resources on ingredients that only provide low levels of protein in fish feeds. This situation can be countered by using locally available ingredients which are of relatively low costs, and which contribute the same or higher levels of protein in fish feeds. Leucaena trichandra leaves for example, which can be obtained at extremely low cost are more cost-effective to use than shrimp meal, although in terms of protein content, shrimps contain twice as much as Leucaena trichandra leaves (Franzel, 2014). The high costs incurred in fish feed formulations on-farm have been reported to contribute significantly to the stagnation of aquaculture (FAO, 2015).

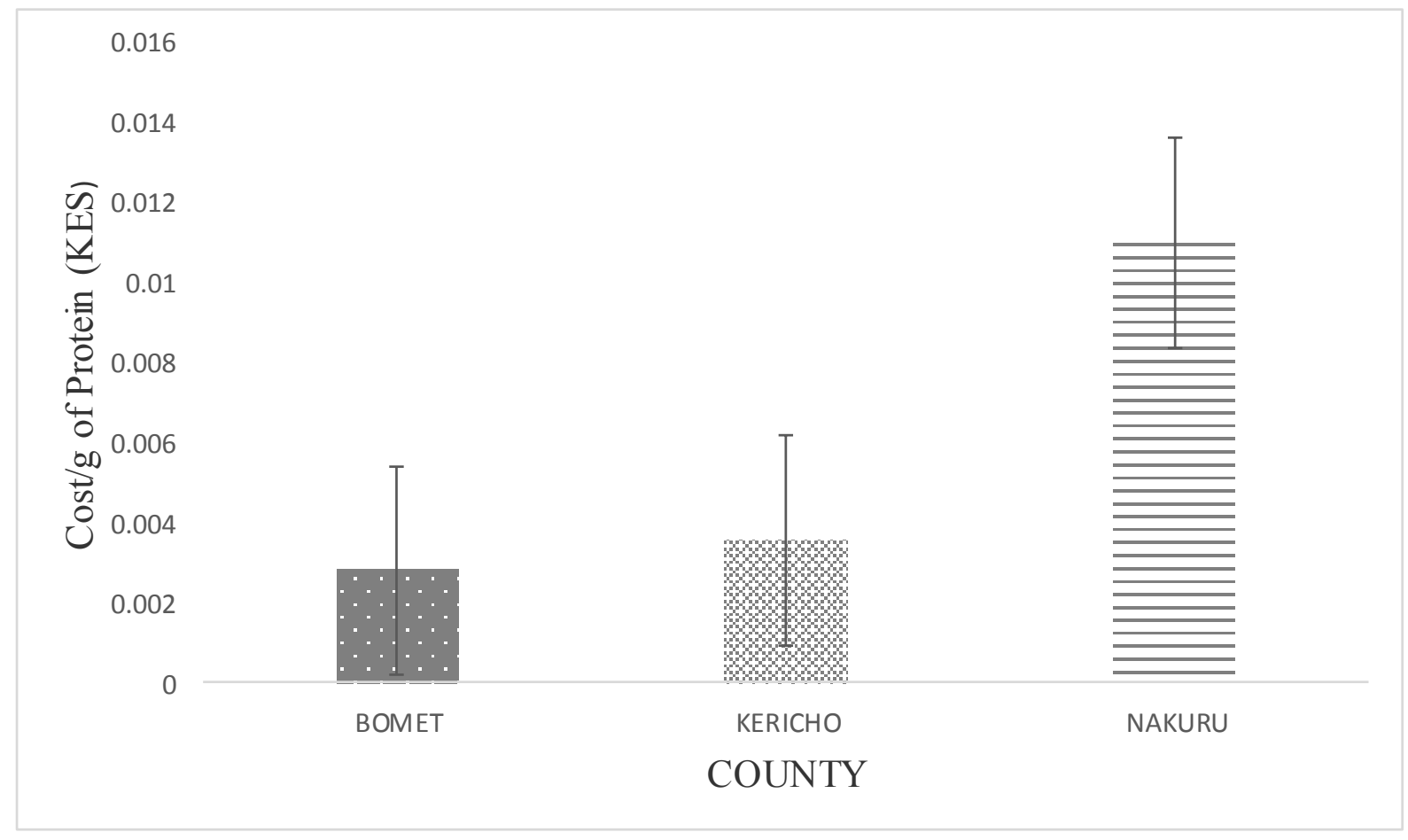

Figure 4: The mean cost per gram of protein in feeds in the three counties. 


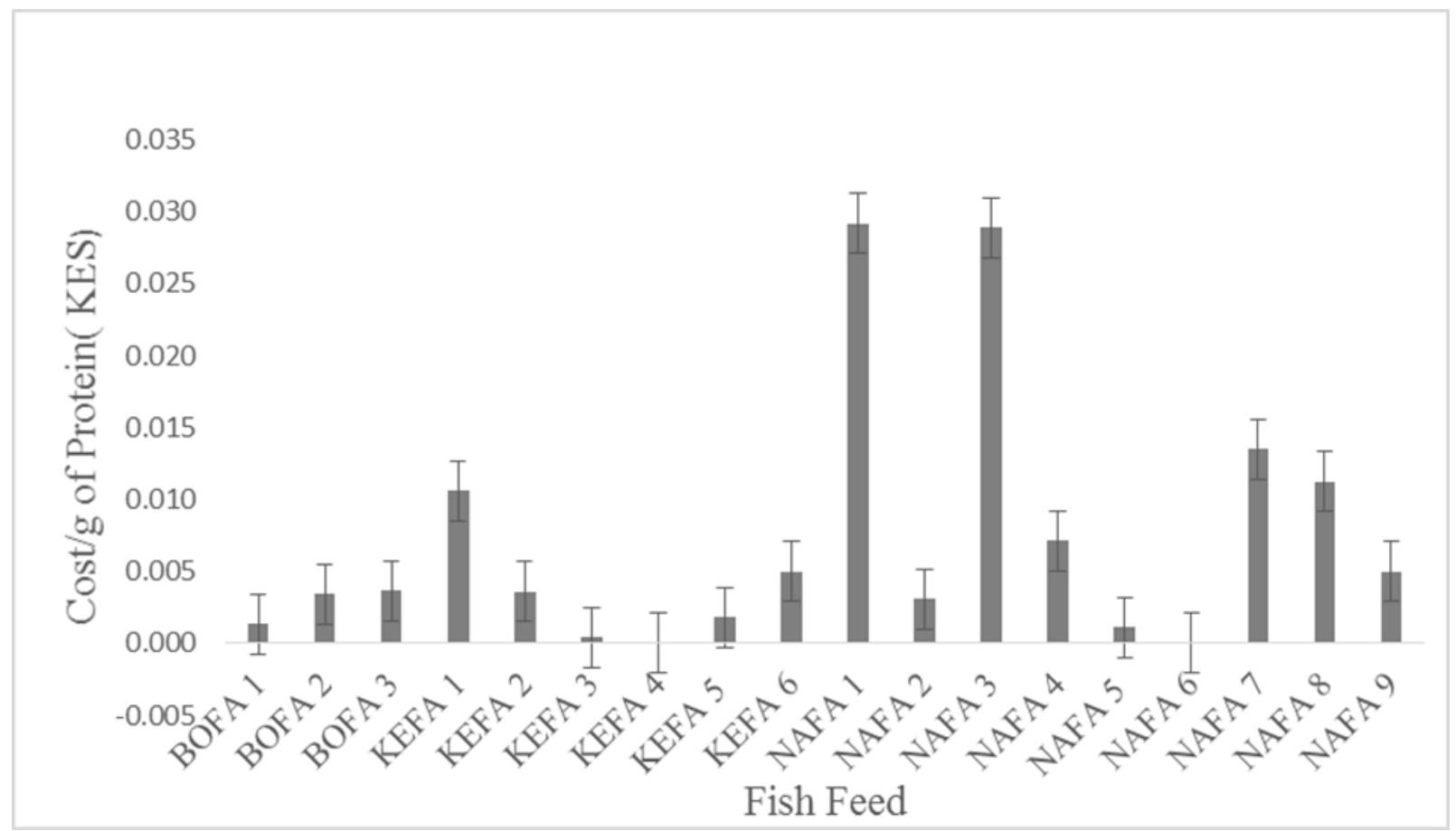

Figure 5: The cost per gram of protein in the 18 feeds analysed from Bomet, Kericho and Nakuru counties.

Legend: BOFA, KEFA, and NAFA are farm codes for Bomet Farm, Kericho Farm and Nakuru Farm, respectively.

\section{Knowledge of Farmers on Nutrient Requirements of Nile tilapia}

Knowledge of the farmer on nutrient requirements of Nile Tilapia was an aspect of interest in this study. This information indicated if the farmer was trained or not. It was also important because the way the farmer applied the information learnt would affect the quality of the on-farm formulated feed. Figure 6 a shows that $35 \%$ of the farmers had been trained in Bomet County. The group of farmers who admitted to have had no training on fish farming, used trial and error method in fish feed formulation. Those who had the moderate to high knowledge on nutrient requirements of Nile tilapia had attended training at least twice over one year and yet applied Pearson's Square Method, whenever they formulated fish feed on-farm.

Sixty percent of the farmers who took part in the study, were appropriately trained. Three quarters of them were from Nakuru County (Figure 6b). Proper management practises are important in aquaculture, as they determine the level of production (Pillay, 1990). Management practises range from the daily, weekly and yearly activities that enhance operations of a fish farm. Ngwili (2014) noted that the right experience, proper information and sufficient knowledge are the key pillars to proper management of fish farming. Inadequate outreach programmes and inefficiency in dissemination of technology to farmers, has been shown to be the major reason for the slow development of the aquaculture sector (Kiptot, 2012; Shitote, 2012; Ngwili, 2014). In this study, more than $30 \%$ of the farmers had no training on fish farm management. Higher results were reported by Shitote (2012), who recorded 95\% of farmers in Western Kenya, faced challenges in managing their fish farms due to lack of appropriate training. The high percentage of untrained fish farmers has been attributed to challenges facing the organizations responsible for providing extension services in the aquaculture sector. From the results of this study, fish farming extension services are mainly provided by the Government through the State Department of Fisheries, Aquaculture and the Blue 
Economy, through collaboration with affiliate organizations. Apart from the State Department of Fisheries and Aquaculture, (Ngwili (2014) suggested that Non-Governmental Organizations, Radio Stations and Social Media could be used to sufficiently disseminate practical information to farmers. These suggestions arose as a result of the major challenges facing extension services offered by the National-level of Government. The reasons for the poor performance of the training organizations include: low funding of the sub-sector, understaffing and lack of expertise by the extension service providers. These challenges were also echoed by Shitote (2012). On the other hand, lack of entrepreneurial skills among farmers, further amplifies the problem. The formation of farmers' cooperative societies in Bangladesh proved to be effective in developing entrepreneurial skills among farmers who shared vital management information among themselves during meetings (Saha, 1985) and thus enhancing the dissemination of information. The results of this study agree with the findings of Saha (1985). In this study, there were more cooperative societies in Nakuru County, with more than $40 \%$ of trained farmers who used the Pearson Square Method in fish feed formulation, and who attained more than $25 \%$ crude protein in their feeds, coming from the county. Halver (2002), emphasised that proper feed formulation is based on sufficient knowledge on specific nutrient requirements of the fish and knowledge on specific nutrient constituents of feed ingredients. As fish farming is a scientific practice, the experience of the farmer alone cannot achieve proper skills, as was shown in this study. Proper aquaculture management can be achieved through proper training of farmers combined with such practises as on-farm demonstrations by extension workers and the formation of farmer cooperative societies to enhance entrepreneurial skills.

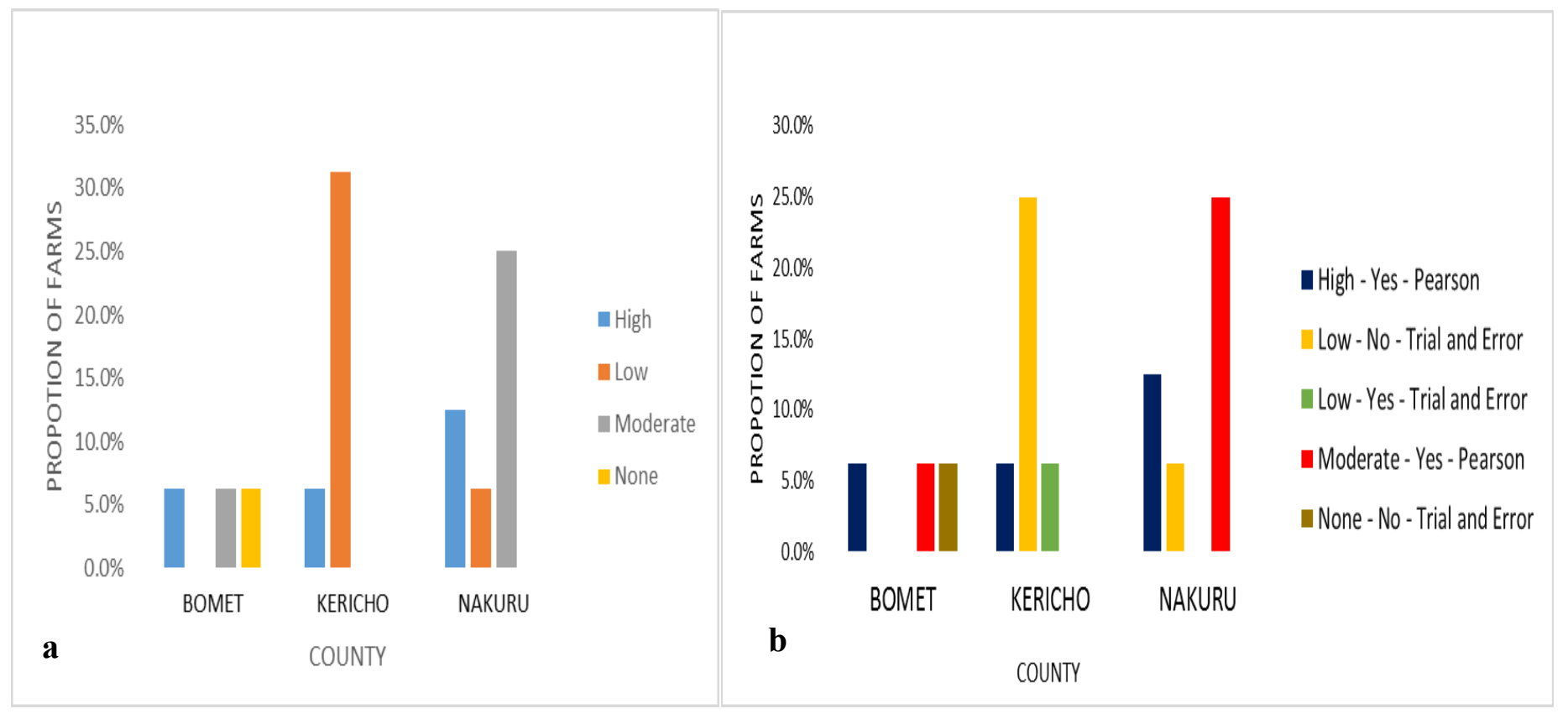

Figure 6a and 6b: Extent of Farmers' Application of Knowledge at Feed Formulation and Fish Production

\section{Feed Management Practices}

This study made observations of how the on-farm formulated fish feeds were handled in terms of storage and supply to the fish. These two aspects were assumed to have effects on the proximate composition of the feed and on the quality of pond water, respectively.

The two main feed storage containers that were used in the enterprises studied were gunny bags and plastic 
bags. Storage in plastic bags was observed in equal proportion $5 \%$ (Figure 7 ) in the three counties. It also emerged that $15 \%$ of farmers who stored their fish feeds in plastic bags did not have appropriately structured storage rooms with wooden racks, as they placed the feeds directly on cement and earth floors. Most of those who placed the gunny bags containing feed on floors came from Bomet County. However, Seventy three percent of the farmers in the three counties stored the feeds in gunny bags on raised wooden platforms.

Fish feed represents the major production cost for fish farmers, and therefore great care is necessary in its handling. Prior to use, the farmers often stored their feed for a week or even months, in large buckets at the pond or cage sites. Although these buckets are usually covered by lids, excessive heat can negatively affect the nutrient composition of the feeds (Bhujel, 2013), as the containers were kept outdoors. This study established that farmers using on-farm formulations, produced feeds just enough to be used for a day to two weeks, while those using commercial feeds bought them in bulk during low price season to last for more than a month in order to keep costs down through economies of scale. Russo (2010), found out that storage of feed for more than two weeks leads to chemical deterioration. The deterioration is greater when storage temperatures are above $27^{\circ} \mathrm{C}$. Oxidation of lipids occurs in feeds under storage leading to rancidity of the feed at temperatures of more than $20^{\circ} \mathrm{C}$ when room ventilation was taken into consideration (Watanabe, 1982). The ambient outdoor temperatures in the three counties was above $20^{\circ} \mathrm{C}$ for most of the year. Some farmers fermented the on-farm feed so as to increase the shelf-life of the feed. However, these feeds contained high moisture contents of $20 \%$ and above which promoted rotting of the ingredients during storage, according to our observations. Fermentation has been found to increase the shelf-life of feeds, but proper drying of the feed after fermentation and grinding is highly recommended (Samaddar et al., 2015).

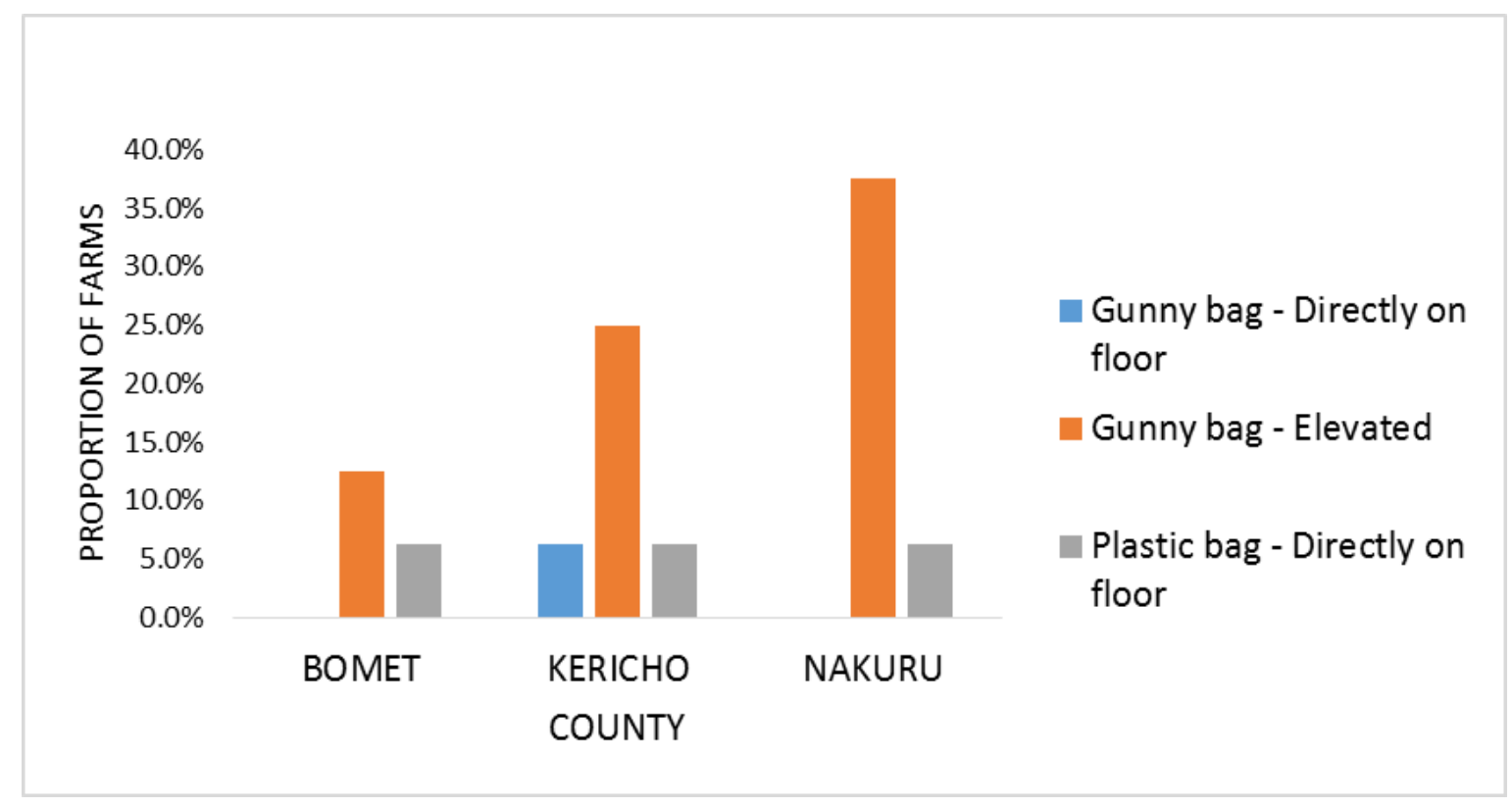

Figure 7: Feed Storage Practices in the three Counties

\section{CONCLUSIONS AND RECOMMENDATIONS}

\section{Conclusions}

It was apparent from the study that the more training sessions the farmers had attended, the greater the use of the Pearson Square Method for on-farm feed formulation. The extent to which farmers were trained also influenced the level of the application of appropriate management practises in Nile Tilapia culture. 


\section{Recommendations}

The study recommends that both national and county governments ensure farmers are properly trained on the use of the scientifically-tested Pearson Square Method to formulate on-farm made fish feeds. The application of good fish management practices be adhered to by farmers for good results. In addition, credit facilities to farmers or subsidy of fertilizer, seed, feeds, etc. be provided alongside appropriate extension services.

For a wider understanding of the sub-sector, we recommend that similar studies be carried out in other areas of Kenya.

\section{ACKNOWLEDGEMENT}

We wish to acknowledge the Austrian Development Agency for funding the study, the State Department of Fisheries and Aquaculture personnel in the three Counties for help with the planning of the fieldwork and the farmers for working closely with the research team.

\section{REFERENCES}

Abowei, J. \& Ekubo, A. (2011). A review of conventional and unconventional feeds in fish nutrition. British Journal of Pharmacology and Toxicology 2(4), 179-191

Bhosale, S.V., Bhilave, M. \& Nadaf, S. (2010). Formulation of fish feed using ingredients from plant sources. Research Journal of Agricultural Sciences 1(3), 284-287.

Bhujel, R.C. (2013). On-farm feed management practices for Nile tilapia (Oreochromis niloticus) in Thailand. FAO Fisheries and Aquaculture Technical Paper No. 583.

Bowman. J., Omolo., B. \& Ngugi, C.C. (2007) A New Guide to Fish Farming in Kenya. Oregon State University,College of Agricultural Science, Aquaculture Corvallis, Oregon, USA.

FAO. (2013). Fishery Statistics. Found at: http://www.fao.org/fishery/countrysector/naso kenya/en. Data accesed on $22 / 08 / 016$

FAO. (2015). FAO Yearbook, Fisheries and aquaculture statistics 2015. Found at: http://www.fao.org/ publications/en/. Date accessed 30/08/2016.

Franzel, S., Carsan, S., Lukuyu, B., Sinja, J. \& Wambugu, C. (2014). Fodder trees for improving livestock productivity and smallholder livelihoods in Africa. Current Opinion in Environmental Sustainability 6, 98-103.

Government of Kenya. (2013). Fish Farming Enterprise Productivity Programme-Phase 2 (proposal), Ministry of Fisheries Development, Nairobi.

GoK. Fisheries Annual Statistical Bulletin. (2016). State Department for Fisheries and the Blue Economy, Nairobi.

Halver, J.E. \& Hardy, R.W. (2002). Fish nutrition. Academic Press. Rome, p 159-189.

Kenya National Bureau of Statistics (KNBS). (2017). Economic survey: KNBS, Nairobi.

Kiptot, E. \& Franzel, S. (2012). Gender and agroforestry in Africa: a review of women's participation. Agroforestry Systems 84(1), 35-58.

Kwikiriza, G., Namulawa, V., Wadunde, A., Abaho, I. \& Ondhoro, C. (2016). Proximate nutrient composition and cost of the selected potential fish feed ingredients in Lake Victoria basin, Uganda. International Journal of Fisheries and Aquatic Studies 4(3), 611-615.

Liti, D., Cherop, L., Munguti, J. \& Chhorn, L. (2005). Growth and economic performance of Nile tilapia (Oreochromis niloticus) fed on two formulated diets and two locally available feeds in fertilized ponds. Aquaculture Research 36, 746-752.

Lukuyu B., Franzel S., Ongadi P.M. \& Duncan, A.J. (2011). Livestock feed resources: Current production and management practices in Central and Northern Rift Valley provinces of Kenya. Livestock Research for Rural Development 23, 112. 
Musiba, M., Ngupula, G.W., Kashindye, B.B., Elison, M., Shoko, A.P., Ndikumana, J. \& Katunzi, E.F.B. (2014). Performance of locally formulated feeds for rearing of African catfish in Tanzania. African Crop Science Journal 22, 979-986.

Ngugi, C.C. \& Manyala, J.O. (2009). Assessment of national aquaculture policies and programmes in Kenya. Sustainable Aquaculture Research Networks in Sub Saharan Africa. EC FP7 Project.

Ngwili, N.M. (2014). Characterization of fish farming systems in Kiambu and Machakos counties, Kenya (Doctoral dissertation, University of Nairobi).

Pillay, T.V.R. (1990). Aquaculture: Principles and Practises. Oxford Publishers, Oxford, ISBN: 0852381689.

Russo, J.R. \& Yanong, R.P. (2010). Molds in fish feeds and aflatoxicosis. Journal Mycologi 21, 1-4.

Saha, R.K., Rahman, M.M. \& Islam, M.M. (1985). An Economic Investigation into Pond Fish Farming under Different Management Types in an Area of Bangladesh. Economic Affairs 30(2), 105.

Samaddar, A., Kaviraj, A. \& Saha, S. (2015). Utilization of fermented animal by-product blend as fishmeal replacer in the diet of Labeo rohita. Aquaculture Reports 1, 28-36.

Shitote, Z., Wakhungu, J. \& China, S. (2001). Challenges facing fish farming development in Western Kenya. Greener Journal of Agricultural Sciences 3(5), 305-311.

State Department of Fisheries and the Blue Economy. (2016). Aquaculture in the Republic of Kenya. Found at: http://www.coastweek.com/3627 aquaculture. 2016. Data accessed on 15/09/2017.

Watanabe, T. (1982). Lipid nutrition in fish. Comparative Biochemistry and Physiology Part B: Comparative Biochemistry 73(1), 3-15. 